\title{
Cultural Tourism and The Use of Local Wisdom in The Bancakan Salak Galengdowo, East Java
}

\author{
Herlina Suksmawati ${ }^{1}$, Dias Pabyantara ${ }^{2 *}$, Praja F. Nuryananda ${ }^{2}$ \\ ${ }^{1}$ Department of Communications, Faculty of Social and Political Science, Universitas Pembangunan Nasional "Veteran" \\ Jawa Timur, Surabaya, Indonesia \\ ${ }^{2}$ Department of International Relations, Faculty of Social and Political Science, Universitas Pembangunan Nasional \\ "Veteran" Jawa Timur, Surabaya, Indonesia
}

\begin{abstract}
The research aimed to elaborate on the common value represented by Bancakan Salak of Gelengdowo Village. Qualitative phenomenology was used to obtain a comprehensive understanding of the research problem. The data collection techniques used in this research is observation of both preparation and due day process. The semi-structured interview was conducted with the chief of the committee, local government representation, local youth figure, and two elders while checking the previous studies to get a comprehensive picture. The finding consists of three-part: (1) the preparation stage has substantial collectivism value, (2) the word bancakan finds its intrinsic value in the long tradition of bancakan practice by the community to express their gratitude upon God blessing, (3) the culture of almsgiving reflected in the tumpeng-shaped salak. The community has been practicing those three values since the beginning. Therefore it inspires and reflected in the creation of Bancakan Salak.
\end{abstract}

Keywords: bancakan salak, Galengdowo, local wisdom, social practice.

\section{INTRODUCTION}

Galengdowo, a village located in the slope of Mount Anjasmoro Jombang East Java, has developed a form of cultural attraction that articulating community shared value in the way of the festival Bancakan Salak that held annually since 2016. This cultural attraction is in response to the three problems faced by local government, first the stagnation of salak (snake fruit) as a major local commodity, second the fading bancakan as local wisdom, and third the longterm effect of urbanization.

The first problem lingers on how the locals are facing difficulties selling their majority of salak production. Local farmers were able to produce approximately 2 tons salak in single harvest time. Unfortunately, most of them can not be sold in broad ways due to a lack of branding. The best grade, which mostly sold to the traditional market, costs around IDR 3,0004,000 per kilos. The rate is considered low compared to another region, which is around IDR 5,000-6,000.

The second problem is, bancakan as local wisdom has been fading since the late 1990s. The

\footnotetext{
* Correspondence address:

Dias Pabyantara

Email : diaspabyantara.hi@upnjatim.ac.id

Address: Faculty of Social and Political Science, UPN "Veteran" Jawa Timur, Rungkut Madya, Gn. Anyar, Surabaya, East Java 60294.
}

elders stated that in late 1990 when the basic food is inflating, locals can't afford to held bancakan as done before. The bancakan rituals believed by the locals as their place to share and getting to know each other well as a member of the community. The fading of bancakan as a gathering forum the social cohesion eroded, resulting in a more individual community. The last and more pressing problem is that Galengdowo is currently facing an impedance of worker deficiency due to massive urbanization. The youth is more attracted to work outside their village to get more significant wages. It is a typical problem that happened in most rural areas.

In response to those problems, the local government has constructed Bancakan Salak, a form of cultural attraction that combining both salak (snake fruit) and bancakan as their valuable local assets. The combination of domestic product and local value aimed to increase locals' well-being, therefore in the long term, and the youth is interested in coming back and helping rebuild their village.

Bancakan Salak that held annually since 2016, usually held in May, where salak (snake fruit) is in prime condition to be harvested. What is interesting is how Bancakan Salak is symbolized. Approximately two tons of salak (snake fruit) were arranged resembling a tumpeng, a traditional dish that always used for celebration in Javanese culture [1]. The step by step of 
Bancakan Salak is as following. The total amount of salak stacked in a tumpeng form, a triangle shape heightened around 15 meters. The event begins with praying together, followed by sharing out the tumpeng salak for free to the attendee. It is intriguing, considering that the culture of bancakan in the middle of the Galengdowo community is no longer becomes a daily practice.

After three years, Bancakan Salak is starting to have a positive impact on both the social and economic conditions of Galengdowo community. Overall salak (snake fruit) prices of Galengdowo is stabilizing around IDR 7,000 - 8,000. The standard is increasing compared to before, which exists in IDR 3,000 - 4,000. Along with material benefit, the community of Galengdowo also developing more sense of mutual assistance (AS and SG Personal Interview, 2019).

Based on the background mentioned before, this study aimed at interpreting what kind of local value represented in the process of Bancakan Salak. To achieve a comprehensive understanding, this paper will elaborate on the meaning of each concept; bancakan, tumpeng, and the process of festival for Galengdowo community. To get systematic explanations, this writing will first, explaining the step by step process of Bancakan Salak festival. This section is vital to understand the value that articulated in the process for the Galengdowo Community. Knowing this, we move to elaborate what the meaning of bancakan process for the community of Galengdowo. Moreover, finally, the writer discussed how the bancakan culture represented as a cultural tourism symbol within the Bancakan Salak process.

\section{MATERIALS AND METHODS}

This research is drawn in the qualitative tradition, using phenomenology methods to extract and interpret collective value that represented in the practice of Bancakan Salak. Knowing the collective value, we expect that it could be a fruitful acknowledgment for Bancakan Salak tourism branding, and generally provide a broader perspective on the development of local tourism of Galengdowo.

The research was mainly conducted in MayJune 2019, located specifically in Galengdowo village, Jombang, East Java, but long before that, researchers have regular first-hand interaction with locals. Using primarily qualitative methodology, it emphasizes the participatory engagement, active participation of the researcher into daily basis activities of the local community [2]. It was chosen to get a comprehensive and systematic explanation of the phenomenon, especially in understanding the local community practicing typical shared value [3]. Other than that, the participatory research design made it possible to adjust research methodology to fit in the dynamics of phenomena in the field [4].

\section{Data Collection}

In terms of data collection, researchers divided it into three pieces. The first step is an observation of the whole process of Bancakan Salak. In this phase, we observed how the preparation process happened mainly how the social relations and interaction developed among members of the community. By following the preparation process, we can get a certain sense of how the community finds its universal value in this event. Having it done, we move to the observation of the day of Bancakan Salak as an observation object. We concentrate our observation on three things; (1) the shape of salak tumpeng, (2) the step by step of how committee organized the parade, and (3) the support of youth in the event management.

Having it done, we did a purposive sampling through an in-depth interview to elaborate more on the relations between collective value and social practice. The purposive sampling is done by selecting a specific person that considered having deep knowledge and information concerning the issue. In this research, we did indepth interview with five individuals; they are the head of Bancakan Salak committee concurrently the village head, the village secretary, members of local tourism development group (Pokdarwis), and two of the elders who is the daughter of the first person to settle in the region.

The third stage is document and literature studies to obtain secondary data, to get a comprehensive understanding of phenomena. The literature used mostly resides in the philosophy and history area, although we admit that few publications have been written concerning Galengdowo culture, especially Bancakan Salak. Regarding the mentioned problem, we chose literature that explains the culture of bancakan in the Javanese society generally. Considering Galengdowo has a robust Javanese culture and typical Javanese community, we believe the literature used below will come in handy to provide second layer explanation toward the research problem. 


\section{RESULT AND DISCUSSION}

Value of Bancakan Salak

As a background, Galengdowo dominated by farmers. Their concept of farming is not planting one type of crop, yet they plant many types of crops in a slope that can be harvested for daily basis need. The amount of Salak farmer is approximately $50 \mathrm{~s}$ individual, with annual production around 2.1 tons (AS Personal Interview, 2019). The enormous amount of production was one of the reasons why Bancakan Salak is established. The development then follows the value of bancakan reflected in daily basis practice of the community.

The whole process of Bancakan salak does not limit to the execution day, but also the preparation stage and afterward phase. Back to the first execution in 2016, the preparation stage was involving full participation from the community to decide the mechanism that beneficial for all. In the execution day, most of the community gather in the venue and supporting as long as they can. Afterward, the community shows cooperation by cleaning the venue together.

\section{The Collectivism Value in The Preparation Stage}

The first phase was the preparation stage. In this stage member of the community who will be a stakeholder in the event such as Salak farmer, local youth organization, event committee and people whose house are around the venue, sit together discussing the best way to accommodate every interest. The process was one of local wisdom which often called musyawarah mufakat (deliberation). By definition, deliberation is to communicate ideas to others by maintaining harmony and accommodating each interest. Thus, methods require all participants to put aside personal objectives and interests and prioritize communal value, which is to preserve harmony among the community [5].

Galengdowo has a tradition to solve disputes through musyawarah mufakat methods. A study once described, in order to appointed irrigation regulator, they regularly held a musyawarah mufakat process [6]. Another research explained that every year, there are tiered musyawarah to decide which development program will be prioritized. Annually, every chief of hamlet will gather their residents to absorb every aspiration raised from grassroots. The aspirations then will be discussed in the Musrembangdes (deliberation of village plan and development), which will decide village budget allocation [7]. The two explanation summarizes how musyawarah has been regular practice in Galengdowo.

Historically speaking, Musyawarah Mufakat methods has a root from Hatta [8]. Hatta tries to combine Habermas thought on the sovereign public sphere and problems of colonialization he faced at that time. While Sukarno focusing on economy deliberation, Hatta came with demokrasi desa (village democracy), a concept that was resembling mutual cooperation in terms of politics and economy. The premise is nothing above common interest. Communal interest must be championed through community collectivism, not individualism [8].

The value of collectivism reflected in the preparation stage. To fulfill the target of two tons

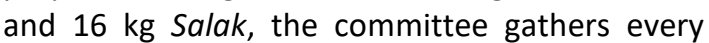
member of the community who has Salak farm. There, the headman presenting his idea concerning the festival and discussed two scenarios to fulfill the target. First, there will be an alms for everyone who has Salak. The amount will fit the large of the Salak farm since everybody has different large of a farm. The dues various, ranging from 5 kilos up to 1 quintal Salak, depends on how abundant crops they have. The rest was bought by the local government at the price of IDR 5000 per $\mathrm{kg}$ (AS, SG, and LS Personal Interview, 2019).

In this process, we have seen collectivism at works. The local government presenting their long term visions for championing local interest, and get full support of the community. No one resisted giving their share to local government (AS Personal Interview, 2019). It can be seen as loyalty and allegiance to the more significant cause, the communal one, which reflects the value of collectivism in the societal practice.

Spirit of collectivism reflected in how people came helping the committee set up the venue without any command or enforcement by the authority. Two or three days before the day, the event committee consists of 30 people who will set up the venue. The preparation included setting up the two tons Salak shaping tumpeng, which heightened about 15 meters. Moved by self-awareness, the people voluntarily helping setting up the venue and prepare salak tumpeng as it was their agenda (AS Personal Interview, 2019). There is no segregation shown by the community. Those who can help will help as much as they can. Those who can not participate donate some refreshments and snacks to show 
their participation in the events. That process occurs without affirmative command from authority (SG Personal Interview, 2019).

One might be able to interpret the collectivist spirit in the youth organization's involvement. Arranging a massive event such as Bancakan Salak, the youth organization takes a vital role by organizing parking lots. It may look simple, yet might turn complicated if not well managed. Bancakan Salak's attendees estimated about 5000 persons in a single day. Compared to the size of the venue only one hectare, it is impossible if all the vehicles parked on site. Before the day, local youth organization communicating potential problems to the residents, resulting in the willingness of residents to let their front yard utilized as parking lots.

The venue located in Bumi Perkemahan Pengajaran, in the peak of Anjasmoro mountain. The landscape is abrupt, not to mention limited space or even space. A rough estimation of the committee, in the 2018 festival not less than 2500 motorcycle and hundreds of automobiles were used by the attendee. The parking lots, using residents' front yard, was $3 \mathrm{~km}$ long. Local people did not ask for sharing profit over parking. The parking revenue goes to the youth organization to increase youth participation and later developing their village (AS and SG Personal Interview, 2019).

The Gratitude Expression in The Word Bancakan

After elaborating on the collectivism value within Bancakan Salak preparation, this section moves to elaborate on the social practice of bancakan that will later be the underlying philosophy of Bancakan Salak. Bancakan, as a social and religious practice, has been practiced by the Galengdowo community. According to LS (87 yo) and SK (93 yo), the tradition goes way back into their parents, SJ, who was the first to settle into the area known as Pengajaran, one of the hamlets of Galengdowo (LS and SK Personal Interview, 2019).

SJ was a coffee plantation overseer who was assigned in the Pengajaran around the 1940s. Back at that time, the land was unpopulated, except for animals and coffee plantations. Years after SJ was on duty, and he felt lonely. Therefore, he invited his colleague, TT, to reside with him up in the Pengajaran. After that, SJ and TT invited other people so that they became few first people to settle in Pengajaran, Pengajaran will later be the place where Bancakan Salak is held (LS Personal Interview, 2019).
The first community to set foot in Pengajaran had a belief in Javanese tradition as guidance. Daily life was guided by Javanese philosophy and tradition rather than relying on religious practice [9]. SK further explains once he was mocked as circus acrobat while making Salat motion. Back in the day, religion had not become everyday practice, unlike nowadays. One of the Javanese tradition that blending with religious practice is bancakan. At that time in Pengajaran, bancakan was a routine practice. This collective memory of tradition shaped the community way of thinking about daily practice until nowadays.

It was confirmed by SK and LS, that LS imitates her father, SJ, in terms of doing bancakan. She still does bancakan on a special occasion, like the beginning of planting season, when her livestock gave birth, harvesting time, or when it comes to their family weton (Javanese calendar). Above all, SK emphasized that nowadays, the culture of bancakan is no longer adhere to Galengdowo community. It has something to do with economic problems. He then continues stating that only LS's family who are still practicing routine bancakan (LS and SK Personal Interview, 2019).

Other than a special occasion like mentioned before, LS doing bancakan on Jumat Legi (Friday, with specific Javanese calendar day), monthly. The step by step of bancakan in Galengdowo nowadays is done in the tradition of Islam. The prayer was taken from the Quran and other Islamic ways such us the Walisongo tradition. She is regularly inviting her 18 neighbors to offer prayer together to the God Almighty. The participants are sitting in a floor mat, forming a square circling a tumpeng.

Bancakan for LS and earlier times community has a deep and positive meaning (LS Personal Interview, 2019). There are two essential points of bancakan, grateful expression and alms. Bancakan meant to be grateful to God Almighty for his blessing. The gratitude was done in the Islamic manner since most of the community are Moslems. She explained further that no matter what your religion or belief is, they sit together and be thankful to God. Sitting together, regardless of social status, religion, or occupation, indicates equality among society (SK Personal Interview, 2019). What bounds them together is a sense of thankfulness.

LS has many grandchildren that now spread in many cities pursuing their carrier. She has high hopes that each of them was guarded by God, given a successful life, and kept away from 
danger and misfortune (LS Personal Interview, 2019). To express her hopes, she is feeding her neighbor through bancakan rituals. She believes that if she did good deeds here by giving alms to others, her faraway family would be treated the same by others. This belief becomes her ground to preserve bancakan practice since the 1950s up to now, despite the others not.

The two positive value of bancakan, gratitude, and almsgiving were confirmed by a local source (AS Personal Interview, 2019). The design of the festival Bancakan Salak was to express gratitude and give alms to others. WT, who was sparking the idea of Bancakan Salak, has the same thought. He imagines what could Galengdowo gives to the others in terms of expressing their gratitude to the Almighty God (WT Personal Interview, 2019). The bancakan words finally chose since it could represent the whole idea of the festival.

This section gives us an explanation that the long-standing history of bancakan practiced has been manifested in the word chosen to be the title of the event. The concept has a long history within Galengdowo Community. Bancakan has been the practice since almost a hundred years ago, shifted from Javanese tradition to religious rituals. Although the nuance has been shifted, the attribute used in the process is mainly the same, tumpeng. The next section will elaborate on how tumpeng means to the Galengdowo Community, which symbolized in the Bancakan Salak festival.

\section{The Almsgiving as Basic Value of Tumpeng}

Tumpeng is mountain-shaped dishes consist of cooked rice and accompanied by side dishes. The side dishes are consist of seven (pitu in Javanese) variety, symbolizing pitulungan, which means help [9]. Other sources stated that it is not always precisely at seven, but it should be in the odd number of side dishes [10]. The side dishes must follow these categories: (1) animals that live on land, for example, chicken, egg, and beef; (2) animals that live in water, for example, milkfish, catfish, and anchovies; and (3) vegetables such as swamp cabbage, carrot, cabbage, string beans, and spinach [9].

Historically speaking, the concept of tumpeng was dated back around the $5^{\text {th }}$ century regarding the fact that Hindu was a significant influence among the Javanese empire [11]. It is believed in Hindu tradition that God resides in the top of the mountain, therefore, to honor the belief they mold the offering resembling a mountain [12].
The word tumpeng consist of two words, tumungkula (bowing to God) and mempeng (diligent) [13]. Thus, tumpeng means praying to God diligently. This notion, as mention before, was the core belief of Javanese culture, no exception for Galengdowo community. Musa also explains the philosophy of tumpeng is to give express awareness that above human, there is God Almighty [10]. Hence, as an offer, tumpeng was made beautiful and delicious [9].

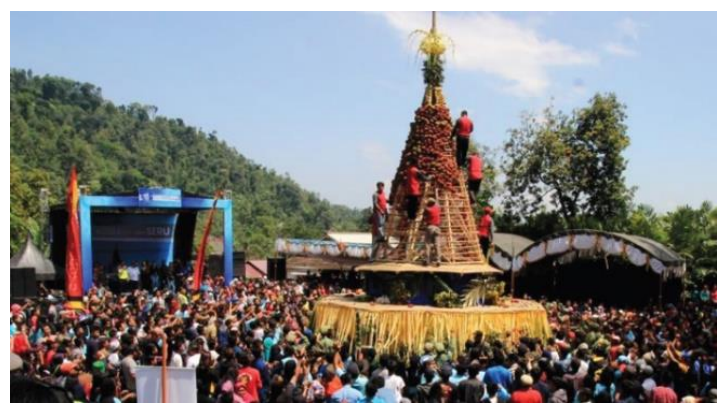

Figure 1. Tumpeng Salak used in Bancakan Salak 2018 Source: Galengdowo.com [14]

On the other hand, tumpeng also has a deep meaning on relations between humans. Tumpeng must be prayed over and then eat together by all the attendees. For those who are unable to attend, the host will deliver the food into their residence. It symbolizes rukun (social harmony) in the Javanese tradition [9]. Following that, Javanese people believe that a person should do good to everybody so that he will also receive good things from others [15].

Based on our interview, Galengdowo society also has that kind of belief and values. The routine bancakan every Jumat Legi meant to pray to God for everyone's safety, good fortune, and good health (LS and SK Personal Interview, 2019). What LS has from her father, SJ, was that humans could never detach from God. Therefore, routine rituals must be done to remind the community how fragile they are without their relations to nature and God. To obtain God's blessing, one needs to offer prayers with no skip. They have to do goods to everyone. They have to have good relations with nature. Only then God gives His blessing to the community [9]. Moreover, that what they have been practicing since early childhood in Galengdowo.

All values reflected in the process of Bancakan Salak. The concept of tumpeng and its philosophy were used in the Bancakan Salak practice. After the event started, one of committee leads a prayer. The Prayer consists of hopes for good health, good fortune, and safety to all. Right after that, the committee started to 
throwing Salak from upper the tumpeng to the below audience. The Salak was given for free, with no fee whatsoever. WT once explained that the meaning of giving away Salak is to representing almsgiving from people of Galengdowo to the broader community (WT Personal Interview, 2019). The tumpeng shape of Salak is an expression of their effort to offer the best of their home to the community and transcendentally to God. Its primary value in the philosophy of tumpeng mentioned before, that the best dish needs to be served to honor God and the broader community. Tumpeng Salak is symbolizing both gratitude to God through the almsgiving activity to achieve God's blessing.

The almsgiving element in the tumpeng finds its compatibility in the societal practice of the Galengdowo community. The reason behind mountain-shaped Salak finds its ground in the mountain-shaped dish that is commonly used by society in the bancakan practice.

\section{CONCLUSION}

Bancakan Salak, as a form of cultural tourism held by the Galengdowo community, is reflecting three values, which believed and practiced by society. Those are the spirit of collectivism, gratitude, and almsgiving. The three of them found in the everyday practice of bancakan using tumpeng that has been done by the community since earlier. The preparation process indicates the spirit of collectivism, where the mutual interest came before the individual. The word bancakan socially means gratitude to the maker. Moreover, tumpeng shape means the almsgiving spirit of the community. Regarding those values, Bancakan Salak brings back the collective memory of the Galengdowo community on how the traditional value of bancakan must be practiced to keep it safe from peril.

\section{Acknowledgement}

The researchers expressed gratitude for Galengdowo community and local government, who have been supported and gives us a warm welcome. Second, the research would like to express gratitude for the Research Grant given by the Universitas Pembangunan Nasional "Veteran" Jawa Timur year 2018/2019.

\section{REFERENCES}

[1] Gardjito, M. 2010. Serba-serbi Tumpeng: Tumpeng dalam kehidupan masyarakat Jawa. Gramedia Pustaka Utama. Jakarta.

[2] Cornwall, A. and R. Jewkes. 1995. What is participatory research? Social Science and
Medicine 41(12), 1667-1676.

[3] Chambers, R. 1992. Rural appraisal: rapid, relaxed and participatory. Institute for Development Studies. Discussion Papers No. 311. Brighton.

[4] Rifkin, S. 1994. Participatory research and health. Proceeding of The International Symposium on Participatory Research on Health Promotion. Liverpool School of Hygiene and Tropical Medicine.

[5] Syukur, F.A. and D. Bagshaw. n.d. Indonesia: the role of indigenous musyawarah mufakat process of mediation. In: Stobbe, S. P. (Ed). 2018. Conflict Resolution in Asia: Mediation and Other Cultural Models. Lexington Books. Washington DC.

[6] Singgih, M., S. D. Hartono, I. Yuwono. 2017. IbM Dusun Galengdowo Desa Galengdowo yang masyarakatnya mengkonsumsi air keruh. Jurnal Pengabdian LPPM Untag Surabaya 2(3), 67-72.

[7] Widiyanti, A. 2017. Implementation of Local participation as part of good governance principles: Galengdowo Village Wonosalam Sub-District, Jombang. Jurnal Akuntansi dan Keuangan 19(2), 59-66.

[8] Muzaqqi, F. 2012. Musyawarah mufakat: gagasan dan tradisi genial demokrasi deliberatif di Indonesia. Jurnal Politik Indonesia 1(2), 21-30.

[9] Jati, I. R. A. P. 2014. Local wisdom behind Tumpeng as an icon of Indonesian traditional cuisine. Nutrition and Food Science 44(4), 324-334.

[10] Musa, M. 2011. Javanese Sufism and prophetic literature. Cultura: International Journal of Philosophy of Culture and Axiology 8(2), 189-208.

[11] Taylor, J. G. 2003. Indonesia: peoples and histories. Yale University Press. London.

[12] Singh, J. P. and M. Khan. 1999. Saptadvipa Vasumati: the mythical geography of the Hindus. GeoJournal 48(4), 269-278.

[13] Mulder, N. 1985. Pribadi dan masyarakat di Jawa. Pustaka Sinar Harapan. Jakarta.

[14] Galengdowo. 2018. PJS Bupati Jombang, apresiasi Bancakan Salak Galengdowo bisa jadi salah satu ikon wisata di Jombang. Available at: http://www.galengdowo.com/ index.php/first/artikel/114.

[15] Sutarto, A. 2006. Becoming a true Javanese: a Javanese view of attempts at Javanisation. Indonesia and the Malay World 34(98), 3953. 